Global Conferences Series:

Sciences and Technology (GCSST), Volume 5, 2020

Seminar Nasional I Baristand Industri Padang (Semnas I BIPD)

DOI:https://doi.org/10.32698/GCS-SNIIBIPD3429

\title{
The effect of fermentation time in the fermentation of lampung robusta coffee (Coffea anephora) with the wet method on the level of preference
}

\section{Pengaruh lama waktu fermentasi dalam fermentasi kopi robusta (Coffea canephora) lampung metode basah terhadap tingkat kesukaan}

\author{
Damar Wiraputra $^{\mathbf{1}}$, Rizki Adrianto ${ }^{\mathbf{1}}$, Masmulki Daniro Jyoti ${ }^{\mathbf{1}}$ \\ ${ }^{1}$ Balai Riset dan Standardisasi Industri Bandar Lampung, Indonesia \\ E-mail: damar.wiraputra@gmail.com
}

\begin{abstract}
The coffee produced by Lampung Robusta coffee farmers has a low-quality taste. The taste of coffee is greatly influenced by many factors, one of which is the way the coffee cherries are processed after harvest into coffee beans. The processing of coffee after harvest is through the fermentation process of the coffee cherries using the wet method. Throughout the fermentation process, metabolites are formed, which are precursor compounds that form flavor and aroma in coffee drinks. This research was conducted with the aim of improving the taste of coffee. The research was conducted by soaking the coffee beans after peeling then adding a 1: 1 LAB (Lactic Acid Bacteria) starter and soaking for A (0 hours); B (8 hours); $C$ (16 hours); $D$ (24 hours). Based on the results of research and organoleptic testing, color preferences (4.9), (4.9), (5.5), (5.4), taste (4.2), (4.5), (4.9), (5.3), aroma (4.8), (5), (5.1), (5.6), overall appearance (4.53), (5.2), (4.8) (4.9). Fermentation carried out on Robusta Lampung coffee beans for 24 hours in treatment D gave an effect that was able to increase the taste or liking of Lampung Robusta coffee with the fermentation process, so based on testing of coffee beans through the optimal fermentation obtained in D coffee fermentation (24 hours).
\end{abstract}

Keywords: coffee; robusta lampung; fermentation; lactic acid bacteria; passions

\begin{abstract}
Abstrak:Kopi yang dihasilkan oleh petani kopi Robusta Lampung memiliki cita rasa yang bermutu rendah. Citarasa kopi sangat dipengaruhi oleh banyak faktor, diantaranya adalah cara pengolahan buah kopi setelah panen menjadi biji kopi. Pengolahan kopi setelah panen yaitu melalui proses fermentasi buah kopi dengan metode basah. Sepanjang proses fermentasi berlangsung akan terbentuk metabolit-metabolit yang merupakan senyawa prekursor pembentuk citarasa serta aroma pada minuman kopi. Penelitian ini dilakukan dengan tujuan meningkatkan citarasa kopi. Penelitian dilakukan dengan cara merendam biji kopi setelah pengupasan kemudian menambahkan starter BAL (Bakteri Asam Laktat) 1:1 dan dilakukan perendaman selama A (kontrol); B (8 jam); C (16jam); D (24 jam). Berdasarkan hasil penelitian dan pengujian secara organoleptik didapatkan secara kesukaan warna $(4.9),(4,9),(5,5),(5,4)$, rasa (4.2), (4.5), (4.9), (5.3), aroma (4.8), (5), (5.1), (5.6), kenampakan keseluruhan (4.53), (5,2), (4.8) (4.9). Fermentasi yang dilakukan pada biji kopi Robusta Lampung selama 24 jam pada perlakuan D memberikan pengaruh yang mampu meningkatkan cita rasa atau kesukaan terhadap kopi Robusta Lampung dengan proses fermentasi, sehingga berdasarkan pengujian biji kopi yang melalui fermentasi yang optimal diperoleh pada fermentasi kopi D (24 jam).
\end{abstract}

Kata Kunci: kopi; robusta lampung; fermentasi; bakteri asam laktat; kesukaan

\section{PENDAHULUAN}

Masyarakat dunia termasuk Indonesia melakukan pengolahan pada kopi menjadi suatu minuman berkualitas yang memiliki harga jual tinggi. Kopi menempati urutan kedua dalam semua komoditas makanan

Copyright (C) 2020, the Authors. Published by Redwhite Press. 
yang dikonsumsi dan diperdagangkan di seluruh dunia(Haile \& Kang, 2019). Indonesia merupakan salah satu penghasil Kopi Robusta terbesar di dunia (492,333ton/tahun), penghasil kopi tersebut berasal dari Lampung dan Sumatera Selatan. Provinsi Lampung sendiri merupakan provinsi yang menjadi salah satu sentra produksi kopi Robusta terbesar di Indonesia dengan persentase sebesar 23,55\% dari total keseluruhan produksi. Hal ini menjadikan provinsi Lampung dapat menjadi potensi yang cukup besar dalam meningkatkan pembangunan ekonomi melalui ekspor produk biji kopi Robusta unggulan(Pusat Data dan Sistem Informasi Pertanian, 2016). Kopi Jenis Robusta (Coffea canephora), juga dikenal sebagai kopi Robusta atau Conillon, lebih kuat dan lebih produktif dibandingkan kopi Arabika, tetapi rasanya kurang populer di kalangan konsumen, dan terutama digunakan dalam formulasi campuran dan espresso. Indonesia merupakan penghasil kopi terbesar ini, diikuti oleh Brazil, Vietnam, Pantai Gading, dan Uganda (Ribeiro et al., 2017).

Daerah penghasil kopi diLampung yaitu Kabupaten Tanggamus,Lampung Utara, Lampung Barat, WayKanan, Pringsewu dan Lampung Timur, dan penghasil kopi Robusta terbesar terletak didaerah Lampung Barat yang mencapai 42.745 ton/tahun. (Pusat Data dan Sistem Informasi Pertanian, 2016).

Maka dari itu, ada potensi untuk meningkatkan nilai dan kualitas biji kopi Robusta. Hal ini bertujuan eksplisit untuk mengurangi perbedaan sensorik, sehingga membuat rasa kopi Robusta lebih mirip Arabika, meningkatkan pilihan konsumen dengan biaya produk akhir yang lebih rendah.(Liu, Yang, Linforth, Fisk, \& Yang, 2019).

Buah kopi (disebut juga berry atau cherry) terdiri dari yang halus, kulit luar yang keras atau pericarp, biasanya berwarna hijau pada buah yang masih mentah tetapi berubah menjadi merah keunguan atau merah tua ketika matang. Pericarp menutupi daging buah yang lembut kekuningan, berserat dan memiliki rasa manis disebut mesocarp luar. Dibagian selanjutnya di bawah mesocarp terdapat lapisan berupa lapisan lendir yang tembus cahaya, tidak berwarna, tipis, agak lengket dan sangat terhidrasi (juga disebut lapisan pektin). Setelah melalui panen buah kopi diolah dengan proses spontan atau fermentasi alami terjadi. Fermentasi dapat berupa metode kering atau basah, dan terkadang kombinasi keduanya, yang disebut proses fermentasi metode semi-kering(Esquivel \& Jiménez, 2012)

Kopi Robusta asli dihasilkan melalui pengolahan pasca panen yang dilakukan dengan metode dan fasilitas yang sangat sederhana, sehingga kandungan airnya relatif tinggi dan masih tercampur dengan bahan lain namun bahan lain tersebut dalam jumlah yang relatif banyak. Metode pengolahan kopi secara kering banyak dilakukan petani karena kemudahan penerapan teknologinya, namun hal tersebut memberikan hasil kopi robusta rendah kualitasnya(Yusianto \& Widyotomo, 2013);(Aklimawati, Yusianto, \& Mawardi, 2014).

Berbeda dengan riset yang dilakukan oleh (Towaha, Aunillah, Purwanto, \& Supriadi, 2014), bahwa proses pengolahan kopi secara basah menghasilkan mutu citarasa kopi Robusta Lampung lebih tinggi dibandingkan dengan pengolahan secara kering.

Dibandingkan dengan metode kering dan semi-kering, pengolahan basah umumnya melibatkan pengelupasan dan pengupasan mekanis, meninggalkan lendir menempel pada biji. Biji kopi yang telah terkelupas ini kemudian difermentasi dalam tangki air besar selama 6 hingga 72 jam(Evangelista, S et al., 2014; Bressani, Martinez, Evangelista, Dias, \& Schwan, 2018; Evangelista, Miguel, Silva, Pinheiro, \& Schwan, 2015).

Tujuan akhir fermentasi kopi adalah menghilangkan lapisan lendir yang tersusun dari senyawa yang kompleks. Bagian lapisan lendir atau mucilage pada lapisan biji kopi adalah zat lengket dan melekat pada pulp kopi, dan terdiri dari sekitar 5\% buah kopi dalam bahan kering(Murthy \& Madhava Naidu, 2012)

Hubungan antara fermentasi dengan profil aroma dijabarkan oleh (Gonzalez-Rios et al., 2007; Jackels \& Jackels, 2005; Liu, Yang, Yang, et al., 2019; Liu, Yang, Linforth, Fisk, \& Yang, 2019), hubungan antara fermentasi dan kesesuaian profil dari aroma kopi dapat digambarkan sebagai sesuatu yang rumit dan sulit digambarkan. Dengan parameter yang dioptimalkan dan kultur starter yang sesuai untuk fermentasi selama penghilangan lendir(mucilage) dalam pemrosesan basah, fermentasi dapat memberikan atribut yang diinginkan pada aroma kopi yang sesuai sementara fermentasi yang tidak terkontrol pasti akan menyebabkan rasa tidak enak. Sementara itu menurut (Illy, A \& Viani, 2005) proses fermentasi basah (wet process) menggunakan bahan mentah hanya dari buah ceri kopi matang yang telah dipetik dengan penuh selektif atau dipisahkan secara mekanis dalam proses itu sendiri

Menurut (Ribeiro et al., 2017) dalam proses fermentasi berlangsung mikroorganisme mengkonsumsi nutrisi dalam pulp dan lendir dan bertanggung jawab dalam memproduksi berbagai metabolit dan asam organik, yang kemudian ada serta masuk dalam biji kopi sehingga mempengaruhi kualitas kopi.

Saat ini proses fermentasi kopi masih dilakukan dengan proses yang tidak terkendali dan spontan sehingga menghasilkan biji kopi dengan kualitas yang tidak konsisten dan tidak dapat diprediksi. Untuk menghubungkan proses fermentasi kopi ke tahap industri yang lebih terkontrol perlu menggunakan kultur 
starter yang ditentukan, penting untuk memahami kontribusi kelompok mikroba tertentu dan jenisnya terhadap proses fermentasi dan kualitas biji kopi (Elhalis, Cox, Frank, \& Zhao, 2020).

Selama pemrosesan basah, kelompok bakteri asam laktat yaitu:Leuconostoc, Lactococcus, dan Lactobacillusadalah kelompok mikroba yang paling umum diidentifikasi, bersama dengan enterobacteria. dan ragi (Pichia dan Starmerella). Beberapa metabolit yang terkait dengan metabolisme bakteri asam laktat diantaranya asam laktat, asam asetat, dan mannitoldiproduksi di lendir juga ditemukan di endosperma(De Bruyn et al., 2017)

Asam asetat dan propionat menunjukkan peningkatan selama fermentasi, yang biasa terjadi pada pengolahan kopi. Kehadiran asam-asam ini diinginkan karena mereka berkontribusi pada keasaman akhir minuman. Asam sitrat, malat, dan suksinat secara alami ada dalam kopi alami(Ribeiro et al., 2017). Tujuan dari penelitian ini adalah untuk mengetahui peran lamanya waktu fermentasi dengan metode fermentasi basah dan kontribusinya terhadap kualitas sensorik kopi.

\section{METODE}

Waktu penelitian dilakukan pada bulan Februari-April 2020. Penelitian dilakukan di Laboratorium THP Unila dan Laboratorium Mikrobiologi Baristand Industri Bandar Lampung. Alat-alat yang digunakan terdiri dari HPLC (high performance liquid chromatography) merk shimadzu tipe LC 200, Laminair air Flow merk Esco, Hot Plate, Vortex, Inkubator merk Thermo Scientific, timbangan analitik, waterbath, autoklaf merk Hirayama, dan peralatan gelas.

Bahan-bahan yang digunakan adalah kopi robusta Lampung dari petani di Liwa, Lampung Barat, Kultur bakteri asam laktat (BAL) Leuconostoc mesenteroides, Lactobacillus plantarum. Medium MRS Brooth untuk mengkultur mikroorganisme fermentasi, Medium PCA/NA untuk menghitung jumlah bakteri, bahan-bahan kimia lainnya untuk kafein.

\section{Pelaksanaan Penelitian \\ Preparasi pembuatan starter BAL (Bakteri Asam Laktat)}

Dari isolate bakteri (BAL) disengkelit 1 ose, diisolasikan ke dalam tabung $9 \mathrm{~mL}$ MRS broth yang berjumlah 10 tabung, kemudian diinkubasikan pada suhu $35 \mathrm{oC} \pm 1$ selama 24 jam, kemudian diisolasikan ke dalam medium MRS broth volume $1 \mathrm{~L}$, diinkubasikan kembali selama 24 jam pada suhu $35 \mathrm{oC}$ dan isolate siap dituang pada saat akan melakukan fermentasi.

\section{Preparasi penghitungan $B A L$}

Metode Penghitungan BAL dilakukan dengan metode total plate count dengan cara starter yang dibuat ditransfer ke pengenceran bertingkat dari pengenceran 10-1 sampai dengan pengenceran10-9. Dengan perbandingan 1:9. Pada pengenceran pertama sebanyak $1 \mathrm{~mL}$ diencerkan dalam $9 \mathrm{~mL}$ larutan BPW (buffer phosphate water). Pengenceran kedua dilakukan dengan $1 \mathrm{~mL}$ yang sudah diencerkan pada pengenceran pertama dimasukkan ke dalam $9 \mathrm{~mL}$ larutan $\mathrm{BPW}$, pengenceran ketiga dan seterusnya dilakukan dengan cara yang sama seperti pengenceran kedua hingga pengenceran yang diinginkan.

Proses penuangan medium dalam petridish dilakukan menggunakan medium NA (natrium agar). Pembuatan medium NA $1000 \mathrm{~mL}$ dilakukan dengan cara medium NA ditimbang sebanyak 28 gram dan dilarutkan ke dalam $1000 \mathrm{~mL}$ akuades sampai homogen, kemudian medium NA disterilkan dengan autoclave pada suhu $121 \mathrm{oC}$ selama 15 menit. Lalu didinginkan sampai suhu 45-50oC. Kemudian sampel hasil pengenceran dimasukkan $1 \mathrm{~mL}$ ke dalam cawan petri dan kemudian medium NA dituangkan \pm sebanyak 10$15 \mathrm{~mL}$ secara pour plate, proses tersebut dilakukan secara duplo dari pengenceran 10-7 sampai dengan pengenceran 10-9. Kemudian, cawan petri digoyangkan membentuk angka 8 supaya medium dengan sampel tercampur homogen. Setelah medium memadat, cawan petridish tersebut diinkubasi dengan posisi terbalik pada suhu $37 \pm 1$ oC selama 48 jam(Hidayat, Kusrahayu, \& Mulyani, 2013).

\section{Proses Fermentasi}

Buah kopi merah dari Biji kopi robusta lampung dipulping atau dikupas kulit luarnya ditimbang $\pm 2,5$ $\mathrm{kg}$, dimasukkan ke dalam masing-masing bak fermentasi, isolate bakteri (BAL) dimasukkan ke dalam bak fermentasi yang berisi biji kopi sebanyak masing-masing $500 \mathrm{~mL}$, proses fermentasi disesuaikan dengan perlakuan $0,8,16$ dan 24 jam dan masing-masing perlakuan diukur $\mathrm{pH}$ nya, setelah proses fermentasi dilakukan dilakukan proses pengeringan biji kopi dalam oven dengan suhu $50 \mathrm{oC} \pm 1$ selama 5 hari. 


\section{Pengamatan}

Uji Sensori

Uji organoleptik yang dilakukan adalah uji hedonik tingkat kesukaan. Sampel akan disajikan dalam cup plastik dengan ukuran seragam. Atribut yang dinilai pada uji organoleptik adalah warna, aroma, rasa, penampakan dan penerimaan secara keseluruhan. Pada form uji organoleptik terdiri dari lima skala penilaian pada setiap atribut yang dinilai, yaitu (1) tidak suka, (2) agak tidak suka, (3) agak suka, (4) suka, (5) sangat suka, (6) amat sangat suka

\section{HASIL DAN PEMBAHASAN}

\section{Kesukaan Terhadap Warna}

Hasil analisis statistik menunjukkan semua perlakuan terhadap kesukaan warna kopi robusta Lampung memberikan pengaruh yang tidak berbeda nyata terhadap tingkat kesukaan panelis terhadap warna kopi yang dihasilkan. Pengaruh fermentasi kopi terhadap kesukaan warna kopi dapat dilihat pada Tabel 1

Tabel 1.Fermentasi Kopi Terhadap Kesukaan Warna Kopi Robusta Lampung

\begin{tabular}{llcl}
\hline Perlakuan & Nilai rata-rata & Penerimaan & Standar Deviasi \\
\hline $\mathrm{A}$ & 4,9 & Suka & 1,651 \\
$\mathrm{~B}$ & 4,9 & Suka & 1,062 \\
$\mathrm{C}$ & 5,53 & Sangat Suka & 0,884 \\
$\mathrm{D}$ & 5,4 & Amat Sangat Suka & 0,718 \\
\hline
\end{tabular}

Keterangan:A: Fermentasi 0 jam, B: Fermentasi 8 jam, C: Fermentasi 16 jam, D: Fermentasi 24 jam

Warna bahan makanan mempunyai peranan yang sangat penting. Ketertarikan terhadap warna merupakan penilaian yang pertama untuk menentukan daya terima terhadap produk makanan. Umumnya konsumen tertarik terhadap warna terlebih dahulu sebelum mempertimbangkan parameter lain misalnya rasa dan nilai gizi. Warna berperan penting dalam penilaian kualitas pangan oleh konsumen; juga dapat digunakan untuk mengoptimalkan proses pengeringan dan mengurangi degradasi senyawa bioaktif (Dong, $\mathrm{Hu}, \mathrm{Chu}$, Zhao, \& Tan, 2017).

Berdasarkan Tabel 1 terlihat bahwa tingkat kesukaan panelis terhadap warna kopi hasil fermentasi kopi berkisar antara 4,9 (agak suka) - 5,5 (suka). Tabel 1 menunjukkan bahwa penilaian panelis secara statistik perlakuan A, B, C dan D tidak berbeda nyata, hal demikian dapat disebabkan karena seduhan kopi yang dihasilkan memiliki warna yang hampir sama, yaitu coklat hingga hitam.

Menurut (Towaha \& Rubiyo, 2013), pengamatan visual dihasilkan dari warna biji kopi semakin gelap dengan semakin lamanya waktu fermentasi, ini menunjukkan bahwa penetrasi mikroba ke dalam biji kopi akan semakin kuat dengan semakin lamanya waktu fermentasi.Selain itu, faktor lain yang mempengaruhi warna seduhan kopi yang dihasilkan, yaitu karena adanya proses karamelisasi gula yang menyebabkan timbulnya warna coklat tua. Berikut hubungan lama fermentasi dengan tingkat kesukaan warna kopi fermentasi pada Gambar 1.

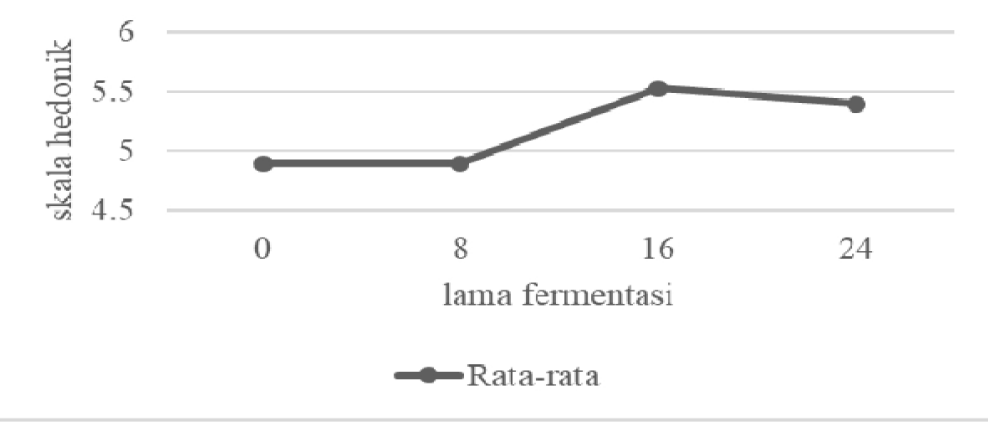

Gambar1. Grafik hubungan antara lama fermentasi terhadap tingkat kesukaan warna kopi fermentasi.

Penilaian sensori pada warna kopi yang diseduh cenderung menunjukan kenaikan berdasarkan grafik hubungan lama fermentasi dengan tingkat kesukaan warna kopi fermentasi walaupun nilai skala hedonik 
berbeda. Menurut penelitian yang dilakukan (Madhava Naidu et al., 2016) namun, proses pengeringan dapat disertai dengan perubahan sifat fisik, kimia, dan komponen-komponen yang peka terhadap panas, antara lain degradasi warna, pembentukan kerak, penurunan kualitas sensorik, inaktivasi bakteri dan enzim, serta hilangnya nutrisi dan aroma.Selain itu, faktor lain yang mempengaruhi warna seduhan kopi yang dihasilkan, yaitu karena adanya proses karamelisasi gula yang menyebabkan timbulnya warna coklat tua (Nopitasari, 2010).

\section{Kesukaan Terhadap Aroma}

Hasil analisis sensoris menunjukkan semua perlakuan fermentasi kopi memberikan pengaruh yang berbeda nyata terhadap tingkat kesukaan panelis terhadap aroma kopi robusta yang dihasilkan. Pengaruh fermentasi kopi terhadap kesukaan aroma kopi robusta dapat dilihat pada Tabel 2.

Tabel 2.Pengaruh Fermentasi Kopi Terhadap Aroma Kopi Robusta Lampung

\begin{tabular}{llll}
\hline Perlakuan & Nilai rata-rata & Penerimaan & Standar Deviasi \\
\hline A & $4,8 \mathrm{a}$ & Suka & 1,454 \\
$\mathrm{~B}$ & $5 \mathrm{a}$ & Sangat Suka & 1,211 \\
$\mathrm{C}$ & $5,1 \mathrm{a}$ & Sangat Suka & 1,203 \\
$\mathrm{D}$ & $5,6 \mathrm{~b}$ & Sangat Suka & 0,966 \\
\hline
\end{tabular}

Keterangan:A: Fermentasi 0 jam, B: Fermentasi 8 jam, C: Fermentasi 16 jam, D: Fermentasi 24 jam

Rata-rata perlakuan yang ditandai dengan huruf kecil yang sama pada lajur yang sama tidak berbeda nyata pada taraf 5\% menurut uji Duncan

Fermentasi dalam pemrosesan pengolahan biji kopi memiliki pengaruh yang signifikan pada aroma kopi yang sesuai (Gonzalez-Rios et al., 2007(Lee et al., 2017). Menurut (Nopitasari, 2010) pembentukan aroma juga tergantung dari terbentuknya senyawa yang mudah menguap dan tidak menguap. Asam-asam mudah menguap terbentuk karena terjadinya degradasi senyawa karbohidrat, protein, dan lemak pada tahap akhir proses pyrolysis.

Fermentasi dalam proses pengolahan fermentasi secara basah memberi pengaruh terhadap kualitas aroma kopi yang diproses secara lebih baik.(Lee et al., 2017)(Wang, Sun, Lassabliere, Yu, \& Liu, 2020).

Berdasarkan hasil uji sensoris pada Tabel 2, nilai rata-rata kesukaan panelis terhadap aroma kopi Robusta Lampung berkisar $(4,8-5,6$.). Hal tersebut menunjukkan panelis masih menyukai aroma yang ditimbulkan kopi pada semua perlakuan akan tetapi panelis lebih menyukai kopi fermentasi variasi D (fermentasi 24 jam). Pada hasil Tabel 2 di atas terdapat beda nyata antara aroma variasi kopi fermentasi A, B dan $\mathrm{C}$ dibandingkan D. Hal demikian menunjukkan bahwa semakin lama waktu fermentasi membentuk aroma kopi yang semakin disukasi oleh panelis. Semakin lama fermentasi menunjukkan bahwa mikroorganisme memanfaatkan substrat di lapisan lendir biji kopi untuk membentuk berbagai jenis metabolit sebagai senyawa precursor pembentuk atribut aroma. Menurut (Lee, Cheong, Curran, Yu, \& Liu, 2015), Enzim ekstraseluler dan asam organik yang dihasilkan dari fermentasi asam laktat masing-masing berpotensi mengarah pada hidrolisis makromolekul seperti karbohidrat, protein, dan polifenol, menghasilkan prekursor aroma penting seperti gula pereduksi, asam amino dan asam klorogenat. Metabolit sekunder, yang dihasilkan selama fermentasi, bisa juga aroma kopi secara langsung atau tidak langsung.

Pemilihan metode pengolahan fermentasi kopi pun sangat memengaruhi akan aroma kopi yang dihasilkan. Menurut (Gonzalez-Rios et al., 2007)(Gonzalez-Aguilar, Villa-Rodriguez, Ayala-Zavala, \& Yahia, 2010), proses fermentasi dalam pengolahan basah bertanggung jawab ataskualitas aroma yang relatif lebih unggul dari kopi olahan. Perlakuan pasca panen terdiri dari pulping dengan disc pulper diikuti dengan fermentasi dalam air untuk memudahkan pembuangan lendir yang dihasilkan kopi dengan sifat yang diinginkan seperti buah, flora dan atribut karamel.

Penelitian yang dilakukan terkait flavor daripada kopi (Sunarharum, Yuwono, \& Nadhiroh, 2018)(Sunarharum, Williams, \& Smyth, 2014) menyatakan berbagai metabolit sekunder dari mikroba dan precursor aroma yang meresap ke dalam biji kopi dan muncul kembali setelah disangrai dan diseduh dalam bentuk senyawa volatil dan nonvolatil yang memiliki pengaruh besar pada sifat sensorik dan organoleptik.

Kecenderungan penilaian aroma yang semakin meningkat berdasar tingkat kesukaan panelis terhadap aroma kopi fermentasi robusta menunjukkan terdapat pengaruh lama fermentasi terhadap aroma kopi tersebut. Berdasarkan tinjauan literatur (Lee et al., 2015)peningkatan kualitas sensorik dari aroma kopi yang ditimbulkan oleh fermentasi selama pemrosesan kopi kemungkinan besar disebabkan oleh modifikasi komposisi prekursor aroma pada biji kopi hijau yang diamati setelah fermentasi.Oleh karena itu, dalam fermentasi kopi peran protein, karbohidrat, dan produk hidrolitiknya masing-masing menjadi sebab kunci 
precursor rasa yang utama dalam pembentukan aroma yang kuat dan berasal salah satunya dari reaksi Maillard. Berikut hubungan lama fermentasi dengan tingkat kesukaan aroma kopi fermentasi pada Gambar 2.

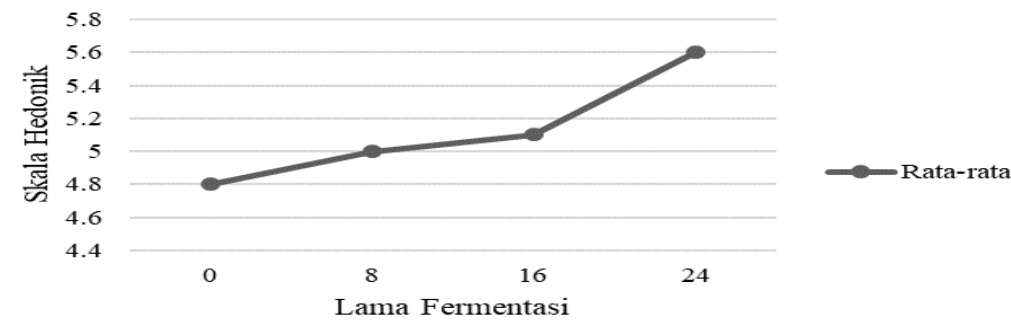

Gambar 2. Grafik hubungan antara lama fermentasi terhadap tingkat kesukaan pada aroma kopi fermentasi.

Berdasarkan kecenderungan dari grafik hubungan lama fermentasi dengan tingkat kesukaan aroma kopi fermentasi dimana cenderung terlihat peningkatan penerimaan kesukaan panelis terhadap aroma kopi seiring dengan peningkatan lama fermentasi biji kopi. Hal demikian dapat dijelaskan dalam penelitian yang dilakukan (Lee et al., 2015) menunjukkan pengaruh berbagai variabel dan proses selama fermentasi kopi terhadap pembentukan aroma selama pemanggangan memerhatikan hubungan yang rumit dan sulit antara fermentasi dan rasa kopi.Reaksi Maillard adalah jalan pembentukan aroma kopi karena bertanggung jawab untuk menghasilkan berbagai tingkatan senyawa yang membuat dampak aroma kopi seperti pirazin, pyrroles, tiol, furanon, piridin, dan tiofena.

\section{Kesukaan Terhadap Rasa}

Hasil analisis statistik semua perlakuan fermentasi kopi robusta Lampung memberikan pengaruh yang berbeda nyata terhadap tingkat kesukaan panelis terhadap rasa kopi robusta yang dihasilkan dari fermentasi kopi dapat dilihat pada Tabel 3.

Fermentasi biji kopi merupakan salah satu metode alternatif untuk meningkatkan kualitas biji kopi tersebut. Setelah proses fermentasi diharapkan dapat menghasilkan kopi dengan meningkatkan kualitas biji kopi tersebut (Farida, A., Ristanti, E., Cahyo K, 2013)

Berdasarkan Tabel 3 dapat dilihat nilai rata-rata kesukaan panelis terhadap rasa kopi Robusta Lampung berkisar 4,2-4,53. Hal tersebut menunjukkan panelis masih menyukai rasa yang ditimbulkan kopi pada semua perlakuan. Penilaian panelis terhadap semua perlakuan fermentasi kopi robusta Lampung memberikan pengaruh yang tidak berbeda nyata terhadap tingkat kesukaan rasa kopi robusta yang dihasilkan sehingga menunjukkan kesamaan untuk setiap perlakuan.

Tabel 3. Pengaruh Fermentasi Kopi Terhadap Rasa Kopi Robusta Lampung

\begin{tabular}{llll}
\hline Perlakuan & Nilai rata-rata & Penerimaan & Standar Deviasi \\
\hline A & $4,2 \mathrm{a}$ & Suka & 1,611 \\
$\mathrm{~B}$ & $4,5 \mathrm{a}$ & Suka & 1,499 \\
$\mathrm{C}$ & $4,9 \mathrm{a}$ & Suka & 0,573 \\
$\mathrm{D}$ & $5,3 \mathrm{~b}$ & Sangat Suka & 0,711 \\
\hline
\end{tabular}

Keterangan :A: Fermentasi 0 jam, B: Fermentasi 8 jam, C: Fermentasi 16 jam, D: Fermentasi 24 jam

Rata-rata kesukaan yang berkisar 4,2-5,3 berada pada rentang agak suka hingga suka. Penilaian kesukaan yang semakin cenderung meningkat menunjukkan peningkatan terhadap tingkat kesukaan akan kopi robusta Lampung yang telah melewati tahap proses fermentasi.

Penelitian kopi yang difermentasi oleh (Hanifah \& Kurniawati, 2013) menyatakan rasa yang diujikan meliputi: tingkat keasaman, after tested (rasa minuman setelah di mulut), bitterness (tingkat kepahitan), body (kegurihan), balance (keseimbangan rasa), dan over all setelah di mulut), bitterness (tingkat kepahitan), body (kegurihan), Balance (keseimbangan rasa), dan over all (rasa keseluruhan). Pada umumnya rasa sangat sulit dimengerti secara tuntas oleh karena selera manusia sangat (rasa keseluruhan). Pada umumnya rasa sangat sulit dimengerti secara tuntas oleh karena selera manusia beragam.

Penilaian panelis berdasar uji statistik menunjukkan hasil yang berbeda nyata, hal itu menunjukkan perlakuan lamanya fermentasi sudah memberikan perbedaan terhadap hasil penerimaan rasa kopi Robusta Lampung. Hal demikian dipengaruhi oleh lama fermentasi pada perlakuan D selama 24 jam, sehingga dalam penelitian ini cita rasa biji kopi terbentuk dari mikroba dalam fermentasi kopi yang menghasilkan metabolit- 
metabolit berupa precursor, asam organik, senyawa aldehid dan ester. Penelitian yang dilakukan (Farida, A., Ristanti, E., Cahyo K, 2013) menyebutkan pada kopi yang dilakukan proses fermentasi, semakin lama waktu fermentasi (lebih dari 12 jam) didapat $\mathrm{pH}$ kopi yang lebih asam. Selain itu, kemampuan inokulum bakteri selulolitik dan bakteri xilanolitik dalam mendegradasi selulosa dan hemiselulosa yang terkandung di dalam kopi, mengakibatkan pemecahan kandungan gula yang nantinya dapat mempengaruhi kandungan asam organik dalam biji kopi.

Selama proses pengolahan kopi yang difermentasi, mikroorganisme menghasilkan beragam metabolitmetabolit. Aktivitas mikroorganisme tersebut dan lama fermentasi menentukan dalam hal konsentrasi gula bebas seperti glukosa dan fruktosa dan asam amino bebas yang berada di sekeliling biji kopi dan selanjutnya memberikan kontribusi pada produksi senyawa Maillard dan volatile selama proses roasting(De Maria, Trugo, Aquino Neto, Moreira, \& Alviano, 1996)(Haile \& Kang, 2019). Berikut hubungan lama fermentasi dengan tingkat kesukaan rasa kopi fermentasi pada Gambar 3.

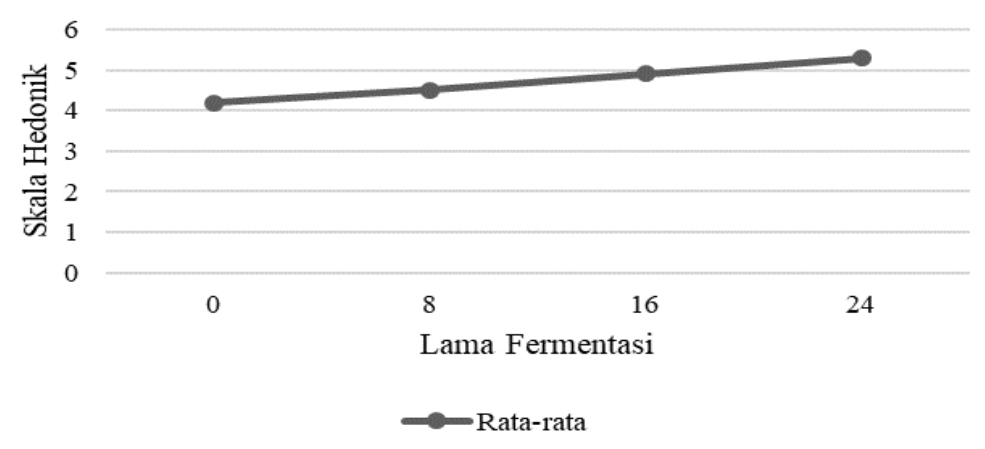

Gambar 3. Grafik hubungan antara lama fermentasi terhadap tingkat kesukaan pada rasa kopi fermentasi.

Lama fermentasi biji kopi pada perlakuan D (selama 24 jam) berbeda nyata dibanding perlakuan lainnya terhadap cita rasa yang diterima panelis. Hal demikian terjadi diakibatkan selama fermentasi mikroba di dalam proses tersebut tumbuh dengan baik dan sangat maksimal dalam memanfaatkan lendir (mucilage) yang menyelubungi seluruh biji kopi tersebut sebagai substratnya.

Grafik hubungan antara lama fermentasi terhadap tingkat kesukaan panelis pada rasa kopi fermentasi cenderung meningkat sejalan dengan bertambahnya lama fermentasi. Hal demikian juga disampaikan (Evangelista et al., 2015)(Hui, Evranuz, Schwan, Silva, \& Batista, 2012)dimana selama fermentasi kopi, mikroorganisme berasosiasidengan melakukan degradasi pulp dan lendir (mucilage) buah, produksi enzim pektinolitik, dan pembentukan alkohol dan asam, terutama asam asetat, laktat, butirat dan asam karboksilat rantai panjang lainnya.

Peningkatan cita rasa dalam proses fermentasi dijelaskan dalam penelitian (Iamanaka et al., 2014), menggambarkan bahwa dari karakteristik aroma yang unggul, kopi yang melalui pengolahan cara basah dapat dikaitkan dengan produksimetabolit mikroba yang merupakan prekursor aroma kopi selama fermentasi.

\section{Kesukaan Terhadap Kenampakan Keseluruhan}

Hasil analisis statistik menunjukkan perlakuan fermentasi kopi robusta Lampung memberikan pengaruh yang tidak berbeda nyata terhadap tingkat kesukaan panelis terhadap kenampakan keseluruhan kopi robusta yang dihasilkan dari fermentasi kopi dapat dilihat pada Tabel 4 .

Tabel 4. Pengaruh Fermentasi Kopi Terhadap Kenampakan Keseluruhan Kopi Robusta Lampung

\begin{tabular}{llll}
\hline Perlakuan & Rata-rata & Skala Sensoris & Standar Deviasi \\
\hline A & 4,53 & Suka & 1,309 \\
B & 5,2 & Sangat Suka & 1,045 \\
C & 4,8 & Suka & 1,166 \\
D & 4,93 & Suka & 0,853 \\
\hline
\end{tabular}

Keterangan :A: Fermentasi 0 jam, B: Fermentasi 8 jam, C: Fermentasi 16 jam, D: Fermentasi 24 jam

Penerimaan panelis terhadap keseluruhan kopi robusta Lampung menunjukkan kesamaan sehingga memberikan nilai skala hedonik yang hampir sama untuk setiap perlakuan atau tidak signifikan perbedaanya, 
namun memiliki rentang rata-rata kesukaan berkisar 4,5- 5,2 berada pada rentang agak suka hingga suka dan kecenderungan hasil penilaian menurut standar deviasi berbeda untuk perlakuan D (fermentasi 24 jam). Sehingga kesimpulannya masih dapat diterima. Menurut(Hanifah \& Kurniawati, 2013), untuk kenampakan fisik, keseluruhan memilki kenampakan yang sama, berkaitan dengan penyangraian pada medium roasting, hingga warna kopi seragam menjadi coklat kehitaman. Berikut hubungan lama fermentasi dengan tingkat kesukaan kenampakan kopi fermentasi pada Gambar 4.

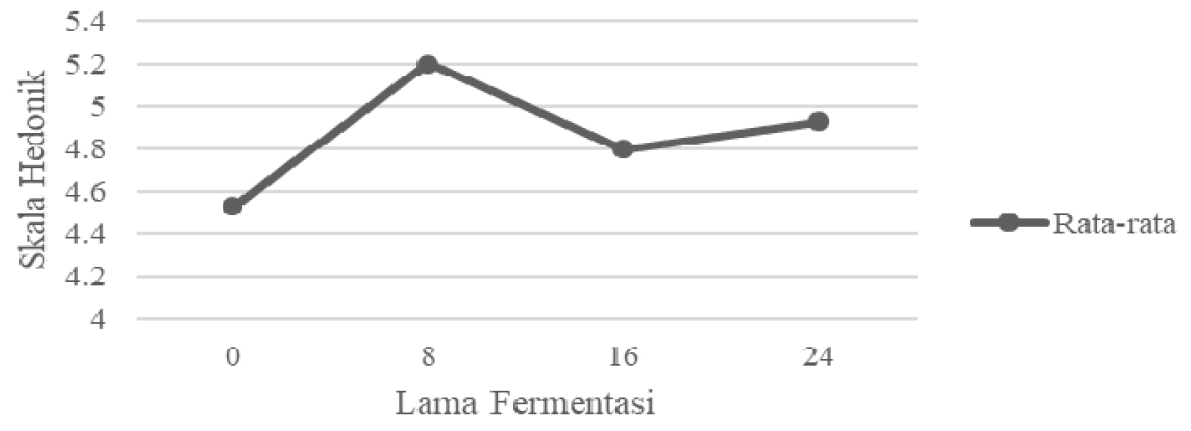

Gambar 4. Grafik hubungan antara lama fermentasi terhadap tingkat kesukaan pada kenampakan kopi fermentasi.

Kenampakan kopi fermentasi yang tidak berbeda dari penilaian panelis yang menilai dan masih masuk ke dalam skala sensoris suka atau secara umum diterima oleh seluruh panelis. Hal demikian diterangkan oleh (Murthy \& Madhava Naidu, 2012) pengeringan yang tepat berkontribusi pada kualitas kopi dalam hal warna, bentuk, dan unsur aromatik. Sedangkan menurut (Massawe \& Lifa, 2010)(Silva et al., 2013) studi mengenai fermentasi kopi memberi tahu bahwa selama proses pengolahan fermentasi cara basah memberikan dampak kepada produk akhir.

\section{SIMPULAN}

Berdasarkan hasil penelitian semakin lama proses fermentasi mampu meningkatkan rata-rata tingkat kesukaan terhadap warna, cita rasa dan aroma kopi robusta fermentasi. Hal ini dibuktikan dengan uji organoleptik yang menyatakan kopi dengan lama waktu fermentasi selama 24 jam lebih disukai dalam hal warna, aroma dan rasa dan berada pada rentang (4) suka dan (5) sangat suka. Fermentasi selama 24 jam oleh BAL berpotensi mengarah pada hidrolisis makromolekul seperti karbohidrat, protein, dan polifenol, menghasilkan prekursor aroma dan cita rasa penting seperti gula pereduksi, asam amino dan asam klorogenat.

\section{UCAPAN TERIMA KASIH}

Kami ucapkan terimakasih kepada pihak-pihak yang telah membantu dalam riset kami antara lain Balai Riset dan Standardisasi Industri Bandar Lampung dan Universitas Lampung yang telah membantu mendukung peminjaman laboratorium serta pemakaian alat dan bahan-bahan kimia dan mikrobiologi.

\section{REFERENSI}

Aklimawati, L., Yusianto, \& Mawardi, S. 2014. Karakteristik mutu dan agribisnis kopi robusta di Lereng gunung tambora, sumbawa. Pelita Perkebunan, 30(2), 159-180.

Bressani, A. P. P., Martinez, S. J., Evangelista, S. R., Dias, D. R., \& Schwan, R. F. 2018. Characteristics of fermented coffee inoculated with yeast starter cultures using different inoculation methods. $L W T$ Food Science and Technology, 92(October 2017), 212-219. https://doi.org/10.1016/j.lwt.2018.02.029

De Bruyn, F., Zhang, S. J., Pothakos, V., Torres, J., Lambot, C., Moroni, A. V., ... De Vuyst, L. 2017. Exploring the impacts of postharvest processing on the microbiota and metabolite profiles during green coffee bean production. Applied and Environmental Microbiology, 83(1), 1-16. https://doi.org/10.1128/AEM.02398-16

De Maria, C. A. B., Trugo, L. C., Aquino Neto, F. R., Moreira, R. F. A., \& Alviano, C. S. 1996. Composition 
of green coffee water-soluble fractions and identification of volatiles formed during roasting. Food Chemistry, 55(3), 203-207. https://doi.org/10.1016/0308-8146(95)00104-2

Dong, W., Hu, R., Chu, Z., Zhao, J., \& Tan, L. 2017. Effect of different drying techniques on bioactive components, fatty acid composition, and volatile profile of robusta coffee beans. Food Chemistry, 234, 121-130. https://doi.org/10.1016/j.foodchem.2017.04.156

Elhalis, H., Cox, J., Frank, D., \& Zhao, J. 2020. The crucial role of yeasts in the wet fermentation of coffee beans and quality. International Journal of Food Microbiology, 333, 108796. https://doi.org/10.1016/j.ijfoodmicro.2020.108796

Esquivel, P., \& Jiménez, V. M. 2012. Functional properties of coffee and coffee by-products. Food Research International, 46(2), 488-495. https://doi.org/10.1016/j.foodres.2011.05.028

Evangelista, S, R., da Cruz Pedrozo Miguel, M., de Souza Cordeiro, C., Silva, C., Marques Pinheiro, A. . \&, \& Schwan, R. . 2014. Inoculation of starter cultures in a semi-dry coffee (Coffea arabica) fermentation process. Food Microbiology, 44, 87-95. https://doi.org/10.1016/j.fm.2014.05.013

Evangelista, S. R., Miguel, M. G. da C. P., Silva, C. F., Pinheiro, A. C. M., \& Schwan, R. F. 2015. Microbiological diversity associated with the spontaneous wet method of coffee fermentation. International Journal of Food Microbiology, $210, \quad 102$. https://doi.org/10.1016/j.ijfoodmicro.2015.06.008

Farida, A., Ristanti, E., Cahyo K, A. 2013. Penurunan kadar kafein dan asam total pada biji kopi robusta menggunakan teknologi fermentasi anaerob fakultatif dengan mikroba nopkor MZ dengan mikroba nopkor MZ-15. Jurnal Teknologi Kimia Dan Industri, 2(3), 70-75.

Gonzalez-Aguilar, G. A., Villa-Rodriguez, J. A., Ayala-Zavala, J. F., \& Yahia, E. M. 2010. Improvement of the antioxidant status of tropical fruits as a secondary response to some postharvest treatments. Trends in Food Science and Technology, 21(10), 475-482. https://doi.org/10.1016/j.tifs.2010.07.004

Gonzalez-Rios, O., Suarez-Quiroz, M. L., Boulanger, R., Barel, M., Guyot, B., Guiraud, J. P., \& SchorrGalindo, S. 2007. Impact of "ecological” post-harvest processing on coffee aroma: II. Roasted coffee. Journal of Food Composition and Analysis, 20(3-4), 297-307. https://doi.org/10.1016/j.jfca.2006.12.004

Haile, M., \& Kang, W. H. 2019. The role of microbes in coffee fermentation and their impact on coffee quality. Journal of Food Quality, 2019, 1-6. https://doi.org/10.1155/2019/4836709

Hanifah, N., \& Kurniawati, D. 2013. Pengaruh larutan alkali dan yeast pada proses pembuatan kopi fermentasi. Jurnal Teknologi Kimia Dan Industri, 2(2), 162-168.

Hidayat, I. R., Kusrahayu, \& Mulyani, S. 2013. Total bakteri asam laktat, nilai pH dan sifat organoleptik drink yoghurt dari susu sapi yang diperkaya dengan ekstrak buah mangga. Animal Agriculture Journal, 2(1), 160-167.

Hui, Y., Evranuz, E., Schwan, R., Silva, C., \& Batista, L. 2012. Coffee fermentation. Handbook of PlantBased Fermented Food and Beverage Technology, Second Edition, (March 2017), 677-690. https://doi.org/10.1201/b12055-49

Iamanaka, B. T., Teixeira, A. A., Teixeira, A. R. R., Vicente, E., Frisvad, J. C., Taniwaki, M. H., \& Bragagnolo, N. 2014. Potential of volatile compounds produced by fungi to influence sensory quality of coffee beverage. Food Research International, 64, 166-170. https://doi.org/10.1016/j.foodres.2014.06.017

Illy, A \& Viani, R. Espresso coffee. , 53 Elsevier Academic Press $§ 2005$.

Jackels, S. C., \& Jackels, C. F. 2005. Characterization of the coffee mucilage fermentation process using chemical indicators: A field study in Nicaragua. Journal of Food Science, 70(5). https://doi.org/10.1111/j.1365-2621.2005.tb09960.x

Lee, L. W., Cheong, M. W., Curran, P., Yu, B., \& Liu, S. Q. 2015. Coffee fermentation and flavor - an intricate and delicate relationship. Food Chemistry, 185, 182-191. https://doi.org/10.1016/j.foodchem.2015.03.124

Lee, L. W., Tay, G. Y., Cheong, M. W., Curran, P., Yu, B., \& Liu, S. Q. 2017. Modulation of the volatile and non-volatile profiles of coffee fermented with Yarrowia lipolytica: II. Roasted coffee. LWT - Food Science and Technology, 80, 32-42. https://doi.org/10.1016/j.lwt.2017.01.070

Liu, C., Yang, N., Yang, Q., Ayed, C., Linforth, R., \& Fisk, I. D. 2019. Enhancing robusta coffee aroma by modifying flavour precursors in the green coffee bean. Food Chemistry, 281, 8-17. https://doi.org/10.1016/j.foodchem.2018.12.080

Liu, C., Yang, Q., Linforth, R., Fisk, I. D., \& Yang, N. 2019. Modifying robusta coffee aroma by green bean chemical pre-treatment. Food Chemistry, 272(April 2018), 251-257. https://doi.org/10.1016/j.foodchem.2018.07.226 
Madhava Naidu, M., Vedashree, M., Satapathy, P., Khanum, H., Ramsamy, R., \& Hebbar, H. U. 2016. Effect of drying methods on the quality characteristics of dill (Anethum graveolens) greens. Food Chemistry, 192, 849-856. https://doi.org/10.1016/j.foodchem.2015.07.076

Massawe, G. A., \& Lifa, S. J. 2010. Yeasts and lactic acid bacteria coffee fermentation starter cultures. International Journal of Postharvest Technology and Innovation, 2(1), 41-82. https://doi.org/10.1504/IJPTI.2010.038187

Murthy, P. S., \& Madhava Naidu, M. 2012. Sustainable management of coffee industry by-products and value addition - A review. Resources, Conservation and Recycling, 66, 45-58. https://doi.org/10.1016/j.resconrec.2012.06.005

Nopitasari, I. 2010. Proses pengolahan kopi bubuk (campuran arabika dan robusta) serta perubahan mutunya selama penyimpanan. IPB.

Pusat Data dan Sistem Informasi Pertanian. 2016. Outlook kopi 2016 (L. and Y. A. Nuryati, Ed.). Jakarta: Pusat Data dan Sistem Informasi Pertanian Sekretariat Jenderal - Kementerian Pertanian.

Ribeiro, L. S., Miguel, M. G. da C. P., Evangelista, S. R., Martins, P. M. M., van Mullem, J., Belizario, M. H., \& Schwan, R. F. 2017. Behavior of yeast inoculated during semi-dry coffee fermentation and the effect on chemical and sensorial properties of the final beverage. Food Research International, 92, 26-32. https://doi.org/10.1016/j.foodres.2016.12.011

Silva, C. F., Vilela, D. M., de Souza Cordeiro, C., Duarte, W. F., Dias, D. R., \& Schwan, R. F. 2013. Evaluation of a potential starter culture for enhance quality of coffee fermentation. World Journal of Microbiology and Biotechnology, 29(2), 235-247. https://doi.org/10.1007/s11274-012-1175-2

Sunarharum, W. B., Williams, D. J., \& Smyth, H. E. 2014. Complexity of coffee flavor: A compositional and sensory perspective. Food Research International, 62, 315-325. https://doi.org/10.1016/j.foodres.2014.02.030

Sunarharum, W. B., Yuwono, S. S., \& Nadhiroh, H. 2018. Effect of different post-harvest processing on the sensory profile of Java Arabica coffee. Advances in Food Science, Sustainable Agriculture and Agroindustrial Engineering, 1(1), 9-14. https://doi.org/10.21776/ub.afssaae.2018.001.01.2

Towaha, J., Aunillah, A., Purwanto, E. H., \& Supriadi, H. 2014. Pengaruh Elevasi dan Pengolahan terhadap kandungan kimia dan citarasa kopi robusta lampung. Jurnal Tanaman Industri Dan Penyegar, 1(1), 57. https://doi.org/10.21082/jtidp.v1n1.2014.p57-62

Towaha, J., \& Rubiyo, R. 2013. The effect of fermentation on flavor quality of probiotic civet coffee. Buletin RISTRI, 4(2), 175-182.

Wang, C., Sun, J., Lassabliere, B., Yu, B., \& Liu, S. Q. 2020. Coffee flavour modification through controlled fermentations of green coffee beans by Saccharomyces cerevisiae and Pichia kluyveri: Part I. Effects from individual yeasts. Food Research International, 136, 109588. https://doi.org/10.1016/j.foodres.2020.109588

Yusianto \& Widyotomo, S. 2013. Mutu dan citarasa kopi arabika hasil beberapa perlakuan fermentasi : suhu , jenis wadah, dan penambahan agens fermentasi. Pelita Perkebunan, 29(3), 220-239. 